\title{
НОВЫЕ РАКОУСТОЙЧИВЫЕ СОРТА КАРТОФЕЛЯ - ПРОИЗВОДСТВУ
}

\author{
${ }^{1}$ Зеля А. Г., ${ }^{1}$ Зеля Г. В., ${ }^{2}$ Олийник Т. Н.

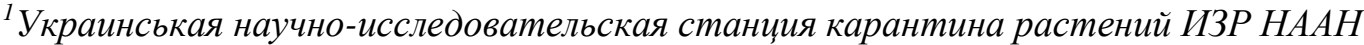 \\ ${ }^{2}$ Институт картофелеводства НААН \\ e-mail: avrelia.zelya@gmail.com
}

\begin{abstract}
: 24 varieties of potato were received from three scientific -research and breeding institutions in Ukraine. They were tested during 2016-2019. There were separated 4 varieties resistant to all causative agents of wart: Glazurna, Strumok, Solocha and Chortytsa, 14 are resistant to 11 (Mizhgirya) agent of wart;10 - to 13 (Rachiv);8 - to 18 (Yasynia); 11 - to 22 (Bistrets). The following potato varieties have a complex resistance to wart are recommended for the implementation in disease sources. The breeders are proposed to use them as donors for the wart resistance interbreeding and receiving the resistant posterity.
\end{abstract}

Key words: potato, wart, pathotype, resistance, selection, imporoving

\section{Введение}

Рак картофеля - Synchytrium endobioticum (Schilb.) Perc. - опасное карантинное заболевание. Он относится к порядку простых грибов и является внутриклеточным облигатным паразитом. У возбудителя рака выражена сортовая специализация по отношению к основному растению-хозяину - картофелю. Он узко специализирован и поражает растения из семейства пасленовых: картофель, томаты, паслен сладкогорький, паслен черный, физалис и др. $[1,2]$. Возбудитель может сохраняться в почве в виде зимних и летних зооспорангиев с зооспорами по данных J. Pzetachewich до 46 лет [3].

Рак картофеля впервые был выявлен в 1888 году в Австро-Венгрии. Позднее - в Англии в 1898 г;; до 1902 года несколько очагов отмечены в Шотландии, Уэльсе и Ирландии. В США рак появился в 1918 году. В Норвегии очаги рака были выявлены в 1914 году, в Швеции - в 1915. В Польше - в 2008 году, в Турции - в 2009 году [4]. На сегодяшний день очаги рака картофеля зарегистрированы в 38 странах мира (Европе, 
Азии, Африке, Северной и Южной Америке); возбудитель был отнесен к перечню регулированных карантинных организмов А2 [5].

По данным ЄОКЗР (Європейской и Среднеземноморской организации карантина и защиты растений - 2018 г.) уже идентифицированы 40 различных патотипов гриба. На сегодяшний день отмечено появление новых патотипов, которые отличаются от распространенного патотипа 1, в Германии, Чехии, Словакии, Польше, Турции, Греции, Перу, Канаде (о. Ньюфаундленд), Индии, Италии. В Украине зарегистрированы 5 патотипов возбудителя рака: Д1 - далемский (обычный) патотип и 4 агрессивных: 11- Межгорский; 13 - Раховский; 18- Ясинивский и 22 - Бистрецкий [6].

Рак картофеля наностит большой ущерб картофелеводству. Он способен уменьшить урожай картофеля на 80-90 \%, особенно на приусадебных участках.

Для борьбы с раком картофеля использують разные методы: агротехнические, химические и биологические. Наиболее економически выгодным, экологически чистым и эффективным способом контроля данной болезни картофеля остается внедрение в аграрное производство устойчивых сортов картофеля $[7,8]$.

На протяжении 82 лет Украинская научно-исследовательская станция карантина растений Института защиты растений НААН Украины проводит работу по оценке и отбора новых выведенных сортов и гибридов картофеля на устойчивость к обычному и агрессивних патотипов возбудителя рака. Внедрение в производство устойчивых сортов в зонах распространения обычного и агресссивних патотипов возбудителя рака способствует увеличению производства картофеля и улучшению фитосанитарного состояния хозяйств с очагами болезни.

Цель исследований: оценить селекционный материал картофеля на устойчивость ко всем патотипам рака и выделять устойчивые сорта, которых можно внедрять в очагах болезни.

\section{Материалы и методы}

Материалом для исследований за 2016-2019 гг. были 24 сорта картофеля, полученные из 4-х селекционных учреждений Украины: Институт картофелеводства НААН, Полесского опытного отделения Института картофелеводства НААН, Института сельского хозяйства Карпатского региона НААН, НПО объединения «Черниговэлиткартофель». Исследования проводили на Украинской научноисследовательской станции карантина растений ИЗР НААН в лаборатории карантинных вредителей и болезней в специальных контейнерах с субстратом почва/перлит, с инфекционной нагрузкой зимних зооспорангиев возбудителя рака картофеля Synchytrium endobioticum (Schilb) Perc. 40 - 50 зооспорангиев/1г субстрата [9], а также с использованием летних зооспорангиев возбудителя болезни и в полевых условиях, непосредственно в очагах болезни. При проведении испытания картофеля на устойчивость к раку использовались методические рекомендации по оценке и отбора селекционного материала картофеля устойчивого к раку, гармонизированные с требованиями ЭС в соответствии с протоколом для Synchytrium endobioticum (Schilb) Perc. 7/28 [10, 11].

\section{Результаты и обсуждение}

В результате проведенных лабораторных и полевых исследований в Черновицкой, Ивано-Франковской и Закарпатской областях выделено 24 сорта картофеля устойчивых к обычному патотипу рака: Ария, Глазурная, Калиновская, Киммерия, Княгиня, Малинская белая, Славянка, Проминь, Легенда, Мистерия, Пикуровська, Слаута, Случ, Струмок, Полеское джерело, Солоха, Сонцедар, Хортица, Чарунка, Червона рута, Щедрик, Фактор, Фея, Хортица, Явор. Данные сорта картофеля 
предлагаются для выращивания в очагах обычного патотипу возбудителя рака. Выявлено лишь поражения сорта картофеля Полесская розовая, как при поражении зимними так и летними зооспорами возбудителя болезни.

В результате испытания к агрессивним патотипам рака выделено 4 сорта картофеля устойчивых ко всем патотипам: Глазурная, Струмок, Солоха и Хортица.

При отборе сортов картофеля устойчивых к 11 (Межгорскому) агрессивному патотипу возбудителя рака 14 образцов картофеля получили оценку устойчивых к болезни: Ария, Глазурная, Киммерия, Калиновская, Княгиня, Мистерия, Слаута, Струмок, Солоха, Сонцедар, Чарунка, Червона рута, Щедрик и Хортица.

В результате оценки устойчивости к 13 (Раховскому) отобрано 10 образцов картофеля устойчивых к данному патотипу: Ария, Глазурна, Малинськая белая, Мистерия, Струмок, Солоха, Сонцедар, Чарунка, Червона рута и Хортица.

При исследовании устойчивости картофеля к 18 (Ясинивскому) агрессивного патотипу отобрано 8 образцов устойчивых к болезни: Глазурна, Калинівська, Малинська біла, Струмок, Солоха, Чарунка, Червона рута и Хортиця.

В результате испытания к 22 (Бистрецькому) агрессивного патотипу возбудителя рака виявлено 11 образцов картофеля устойчивых к данному патотипу: Ария, Глазурная, Киммерия, Калиновская, Малинская белая, Мистерия, Слаута, Струмок, Солоха, Щедрик и Хортица. Сорта картофеля, которые не поразились патотипами возбудителя рака предлагаются для районирования в очагах возбудителя болезни, предлагаются использовать селекционерам для скрещивания в качестве источников устойчивости к раку (табл. 1).

Таблица 1. Результаты оценки и отбора селекционного материала картофеля устойчивого к обычному и 4-м агрессивним патотипам возбудителя рака (2016-2019 р.)

\begin{tabular}{|c|c|c|c|c|c|c|c|c|c|c|c|c|}
\hline \multirow{3}{*}{$\begin{array}{l}\text { № } \\
\Pi / \Pi\end{array}$} & \multirow{3}{*}{$\begin{array}{l}\text { Название } \\
\text { образца }\end{array}$} & \multicolumn{6}{|c|}{$\begin{array}{l}\text { Результаты испытаний к обычному } \\
\text { патотипу }\end{array}$} & \multirow{3}{*}{$\begin{array}{l}\text { Устой } \\
\text { чивость }\end{array}$} & \multicolumn{4}{|c|}{$\begin{array}{l}\text { Устойчивость к агрессивним } \\
\text { патотипам рака }\end{array}$} \\
\hline & & \multicolumn{3}{|c|}{ Лабораторное } & \multicolumn{3}{|c|}{ Полевое } & & \multirow{2}{*}{$\begin{array}{l}\text { Межгорье } \\
(\Pi)\end{array}$} & \multirow{2}{*}{$\begin{array}{l}\text { Рaxов } \\
(13)\end{array}$} & \multirow{2}{*}{$\begin{array}{l}\text { Ясиня } \\
(18)\end{array}$} & \multirow{2}{*}{$\begin{array}{l}\text { Быстрец } \\
(22)\end{array}$} \\
\hline & & $\begin{array}{l}\text { К-во } \\
\text { раст, } \\
\text { шт. }\end{array}$ & $\begin{array}{l}\text { Из } \\
\text { них } \\
\text { пор. }\end{array}$ & \begin{tabular}{|l}
$\%$ \\
пора- \\
жения
\end{tabular} & \begin{tabular}{|l|} 
К-во \\
раст, \\
шт.
\end{tabular} & \begin{tabular}{|l} 
Из \\
них \\
пор.
\end{tabular} & $\begin{array}{l}\% \\
\text { пора- } \\
\text { жения }\end{array}$ & & & & & \\
\hline 1 & 2 & 3 & 4 & 5 & 6 & 7 & 8 & 9 & 10 & 11 & 12 & 13 \\
\hline 1. & Ария & 10 & 0 & 100 & 30 & 0 & 100 & 1 & - & - & + & - \\
\hline 2. & Глазурная & 10 & 0 & 100 & 30 & 0 & 100 & 1 & - & - & - & - \\
\hline 3. & Славянка & 10 & 0 & 100 & 30 & 0 & 100 & 1 & + & + & + & + \\
\hline 4. & Киммерия & 10 & 0 & 100 & 30 & 0 & 100 & 1 & - & + & + & - \\
\hline 5. & Княгиня & 10 & 0 & 100 & 30 & 0 & 100 & 1 & - & + & + & - \\
\hline 6. & Проминь & 10 & 0 & 100 & 30 & 0 & 100 & 1 & + & + & + & + \\
\hline 7. & Легенда & 10 & 0 & 100 & 30 & 0 & 100 & 1 & + & + & + & + \\
\hline 8. & Пикуровская & 10 & 0 & 100 & 30 & 0 & 100 & 1 & + & + & + & + \\
\hline
\end{tabular}




\begin{tabular}{|l|l|l|l|l|l|l|l|l|l|l|l|l|}
\hline 9. & Калиновская & 10 & 0 & 100 & 30 & 0 & 100 & 1 & + & + & - & - \\
\hline 10. & $\begin{array}{l}\text { Малинская } \\
\text { белая }\end{array}$ & 10 & 0 & 100 & 30 & 0 & 100 & 1 & - & + & - & - \\
\hline 11. & Мистерия & 10 & 0 & 80 & 30 & 0 & 80 & 1 & - & - & + & - \\
\hline 12. & Слаута & 10 & 0 & 100 & 30 & 0 & 100 & 1 & - & + & + & + \\
\hline 1 & 2 & 3 & 4 & 5 & 6 & 7 & 8 & 9 & 10 & 11 & 12 & 13 \\
\hline 13. & Случ & 10 & 0 & 100 & 30 & 0 & 100 & 1 & + & + & + & + \\
\hline 14. & Сонцедар & 10 & 0 & 80 & 30 & 0 & 80 & 1 & - & - & + & + \\
\hline 15. & Струмок & 10 & 0 & 100 & 30 & 0 & 100 & 1 & - & - & - & - \\
\hline 16. & Солоха & 10 & 0 & 100 & 30 & 0 & 100 & 1 & - & - & - & - \\
\hline 17. & $\begin{array}{l}\text { Полесское } \\
\text { джерело }\end{array}$ & 10 & 0 & 100 & 30 & 0 & 100 & 1 & + & + & + & + \\
\hline 18. & Чарунка & 10 & 0 & 100 & 30 & 0 & 100 & 1 & - & - & - & + \\
\hline 19. & $\begin{array}{l}\text { Червона } \\
\text { рута }\end{array}$ & 10 & 0 & 100 & 30 & 0 & 100 & 1 & - & - & - & + \\
\hline 20. & Щедрик & 10 & 0 & 100 & 30 & 0 & 100 & 1 & - & - & + & - \\
\hline 21. & Фактор & 10 & 0 & 100 & 30 & 0 & 100 & 1 & + & + & + & + \\
\hline 22. & 10 & 0 & 100 & 30 & 0 & 100 & 1 & + & + & + & + \\
\hline 23. & Фея & 10 & 0 & 100 & 30 & 0 & 100 & 1 & - & - & - & - \\
\hline 24. & Явор & 10 & 100 & 30 & 0 & 100 & 2 & + & + & + & + \\
\hline 25 & $\begin{array}{l}\text { Полесская } \\
\text { (контроль }\end{array}$ & 10 & 10 & 100 & 30 & 10 & 100 & 5 & + & + & + & + \\
\hline
\end{tabular}

\section{Выводы}

1. В результате проведенных исследований по отбору сортов картофеля украинской селекции устойчивых против рака из 24 испытанных сортов выделено 4 сорта устойчивы ко всем патотипив возбудителя рака: Глазурная, Струмок, Солоха и Хортица.

2. При отборе сортов картофеля устойчивых к 11 (Межгорского) агрессивного патотипу возбудителя рака 14 образцов картофеля получили оценку устойчивых к болезни; к 13 (Раховскому) - 10; к 18 (Ясинивскому) - 8; к 22 (Бистрецкому) - 11.

3. Сорта картофеля, которые не поразились патотипами возбудителя рака предлагаются для районирования в очагах возбудителя болезни, селекционерам предлагаются использовать для скрещивания в качестве источников устойчивости к раку.

\section{Библиография}

1. Бондарчук А.А. та інш. Відбір селекційного матеріалу та створення сортів, стійких проти звичайного та агресивних патотипів раку картоплі. Картоплярство України. 2018. № 1-2 (44-45). С. 2-11. 
2. Мельник П. О. Етіологія раку картоплі, біоекологічне обгрунтування заходів його профілактики та обмеження розвитку. Чернівці : Прут, 2003. 284 с.

3. Przetakiewicz J. First report of Synchytrium endobioticum (potato wart disease) pathotype 18 (T1) in Poland. Plant Disease. 2014. Vol. 98, No 5. P. 688-688. URL: https://apsjournals.apsnet.org/doi/abs/10.1094/PDIS-06-13-0646-PDN. (last accessed: 14.09.2020).

4. Çakir E., Demirci F. A new pathotype of Synchytrium endobioticum in Turkey: Pathotype 2. Bitki koruma bulteni. 2017. Vol. 57, No 4. P. 415-422. DOI: 10.16955/bitkorb.34044.1.

5. Obidiegwu J. E., Flath K., Gebhardt C. Managing potato wart: a review of present research status and future perspective. Theoretical and applied genetics. 2014. Vol. 27, No 4. P. 763-780. URL: https://link.springer.com/article/10.1007/s00122-014-2268-0. (last accessed: 14.09.2020).

6. Zelya A. G. et al. Screening of potato varieties for multiple resistance to Synchytrium endobioticum in Western region of Ukraine. Agricultural Science and Practice. 2018. No 3. P. 3-11. DOI: 10.15407/agrisp 5.03.003.

7. Мельник П. О. та інш. Стан селекції картоплі нам стійкість до збудників карантинних хвороб. Вісник аграрної науки. 2012. №1. С. 52-55.

8. Зеля Г. В. Оцінка та відбір селекційного матеріалу картоплі стійкого до раку Synchytrium endobioticum (Schilbersky) Percival. Картоплярство.2012. Вип 41. C.12-19.

9. Зеля Г. В. та інш. Методика оцінки та відбору селекційного матеріалу картоплі, стійкого до раку Synchytrium endobioticum (Schilb.) Perc., гармонізована 3 вимогами СС. Чернівці : Місто, 2015. 24 с.

10. EPPO Standard PM 7/28/1 Synchytrium endobioticum. Bulletin OEPP/EPPO Bulletin. $2004 . \quad$ Vol. 34, No 2. P. 213-218. URL: https://www.furs.si/law/eppo/zvr/ENG/EPPO2004/diag_protokoli_PM7/pm7-28(1).pdf

11. EPPO Standard PM 7/28/2 Synchytrium endobioticum. Bulletin OEPP/EPPO Bulletin. 2017. Vol. 47, No 3. P. 420-440. URL:

12. https://onlinelibrary.wiley.com/doi/epdf/10.1111/epp.12588. (last accessed: 11.09.2020). 